\title{
Efikasi Herbisida Isopropilamina Glifosat Dalam Mengendalikan Gulma Perkebunan Karet (Hevea Brasiliensis) Belum Menghasilkan
}

\author{
Efficacy of Isopropylamine Glyphosate Herbicide in Controlling Weeds in \\ Immature Rubber (Hevea Brasiliensis) Plantation
}

Hendi Pamungkas*, Dad R.J. Sembodo, Rusdi Evizal, and Hidayat Pujisiswanto

Universitas Lampung

*Email: aatpuji75@gmail.com

\begin{abstract}
Rubber (Hevea brasiliensis) is an important plantation crop in Indonesia because its products are used as raw material for rubber industry and source of stock-exchange. The existence of weeds on the rubber land causes competition of growing facilities and affect the growth of rubber plants. One of the most common herbicide active ingredients that used to control immature plant weeds is isopropylamine glyphosate. This research aims to (1) find out the dose of isopropylamine glyphosate herbicide that effectively control weeds in immature rubber cultivation, (2) to know the change of weed's composition due to the application of isopropylamine glyphosate herbicide, (3) to know whether the phytotoxicity of rubber plants occurs due to isopropylamine glyphosate herbicide application. This research was conducted in smallholder rubber plantation in Marga Agung Village, Jati Agung Subdistrict, South Lampung Regency and Weed Laboratory of Agriculture Faculty of Lampung University from November 2016 until March 2017. This research used randomized block design (RAK) with four replicates and six treatment levels dose of herbicide isopropylamine glyphosate herbicide 796,5 $\mathrm{g} / \mathrm{ha}(\mathrm{P1}), 1062 \mathrm{~g} / \mathrm{ha}(\mathrm{P2}), 1327.5 \mathrm{~g} / \mathrm{ha}$ (P3), $1593 \mathrm{~g} / \mathrm{ha}$ (P4), mechanical weeding (P5), and without restraint/control (P6). The homogeneity of various data was tested by Bartlett test, the data additivity was tested by Tukey test, and the difference of median treatment was tested by Least Significant Different (LSD) test at 5\% level. The results showed that: (1) isopropylamine glyphosate herbicide dose 796,5 - $1593 \mathrm{~g} / \mathrm{ha}$ effectively controlling total weeds, grass weeds up to 12 weeks after application and nut grass weeds up to 4 weeks after application, and dose $1593 \mathrm{~g} / \mathrm{ha}$ effectively controlling leaf weeds up to 8 weeks after application, (2) dose 1327,5 - 1593 g/ha effectively controlling Ottochloa nodosa weeds up to 12 weeks after application and Commelina diffuse up to 4 weeks after application, (3) dose 796,5 - 1593 g/ha effectively controlling Cyperus brevifolius weeds up to 4 weeks after application, and doses of 1593 g/ha effectively controlling Asystasia gangetica weeds up to 8 weeks after application, (4) doses of 796,5 - $1593 \mathrm{~g} / \mathrm{ha}$ resulted in changes in weed's composition at 4, 8, and 12 weeks after application, (5) doses 796,5 - $1593 \mathrm{~g} / \mathrm{ha}$ does not poison the rubber plant.
\end{abstract}

Keywords: Weeds, herbicide, isopropylamine glyphosate, rubber

Disubmit : 2 Desember 2017, Diterima: 23 Januar 2018, Disetujui : 14 Maret 2018

\section{PENDAHULUAN}

Karet (Hevea brasiliensis) merupakan tanaman perkebunan yang memiliki nilai ekonomi tinggi. Getah hasil sadapan adalah bahan baku dasar dalam industri karet. Produk hasil industri karet digunakan sebagai bahan baku pabrik crumb rubber (karet remah) yang menghasilkan bahan baku untuk industri hilir seperti 
sepatu, karet gelang, bola, ban, dan lainnya (Purwanta et al., 2008). Karet merupakan salah satu komoditi yang memiliki peran penting sebagai penghasil devisa negara Indonesia. Menurut data Badan Pusat Statistik, (2016), 83,42\% produksi karet Indonesia diekspor ke mancanegara dan hanya sebagian kecil yang dipergunakan di dalam negeri. Dalam perkembangannya, luas areal perkebunaan karet Indonesia selalu mengalami peningkatan. Tahun 2014 luas perkebunan karet yaitu 3.606.245 ha mengalami peningkatan menjadi 3.621.587 ha di tahun 2015 dan 3.639.695 ha di tahun 2016 (Direktorat Jendral Perkebunan, 2016).

Luas lahan tanaman karet di Indonesia terjan di peningkatan, data produksi karet 2013 menunjukkan angka 3.237.433 ton. Pada 2014 terjadi penurunan produksi karet yaitu 3.153.186 ton. Data sementara produksi karet di tahun 2015 yaitu 3.108.260 ton (Badan Pusat Statistik, 2016). Upaya pengembangan sektor perkebunan karet baik secara intensifikasi maupun ekstensifikasi terus dilakukan seiring dengan target tinggi produksi karet. Produksi dari sektor perkebunan karet tidak maksimal salah satunya disebabkan oleh permasalahan gulma. Keberadaan gulma menjadi sangat penting apabila tidak ditangani dengan baik.

Persaingan gulma terhadap tanaman karet TBM menimbulkan kerugian dalam segi sarana tumbuh seperti air, unsur hara, cahaya matahari serta ruang untuk tumbuh (Suparwan \& Haryadi, 2014). Evizal, (2015) menyatakan bahwa kerugian yang ditimbulkan yaitu menunda waktu matang sadap dan mengurangi jumlah populasi tanaman karet. Ferry \& Samsudin, (2014) menambahkan bahwa kerugian lainnya yaitu menurunkan efisiensi pemupukan.

Pengendalian gulma merupakan salah satu faktor penentu keberhasilan dalam budidaya karet. Tjitrosoedirjo et al., (1984) menyatakan bahwa pengendalian gulma memerlukan biaya sebesar $50-70 \%$ dari seluruh biaya pemeliharaan selama tanaman belum menghasilkan (TBM) dan selanjutnya $20-30 \%$ setelah tanaman menghasilkan (TM). Berbagai teknik pengendalian dapat diterapkan untuk mengendalikan gulma salah satunya yaitu pengendalian kimiawi. Pengendalian gulma secara kimiawi merupakan teknik pengendalian yang diminati terutama untuk lahan pertanian yang cukup luas. Senyawa kimia yang digunakan untuk pengendalikan gulma dikenal dengan nama herbisida. Isopropilamina glifosat merupakan salah satu bahan aktif herbisida yang dapat digunakan untuk mengendalikan gulma pada tanaman karet dan termasuk herbisida pascatumbuh serta bersifat nonselektif.

Suatu merek dagang herbisida yang memiliki izin tetap dapat diproduksi, diedarkan, dan digunakan dengan masa berlaku 5 tahun serta dapat diperpanjang perizinannya untuk 5 tahun selanjutnya. Pengujian ulang herbisida dilakukan setiap 10 tahun sekali guna membuktikan kebenaran klaimnya mengenai mutu, efikasi dan keamanan herbisida. Pengujian ulang herbisida dilakukan untuk memperoleh informasi baru mengenai efektivitas bahan aktif herbisida terhadap kemungkinan perubahan jenis gulma baru dalam selang waktu 10 tahun terakhir. Dosis rekomendasi herbisida isopropilamina glifosat adalah $1.062 \mathrm{~g} / \mathrm{ha}$ (nilai A) yang ditetapkan oleh formulator. Lalu dosis rekomendasi (nilai A) ditambah dan diturunkan menjadi beberapa taraf dosis yang diuji. Pengujian ini diharapkan dapat diketahui dosis herbisida yang efektif mengendalikan gulma pertanaman karet TBM, dan pengaruhnya terhadap tanaman karet.

\section{METODE PENELITIAN}

Penelitian dilaksanakan di kebun karet rakyat di desa Marga Agung, Kecamatan Jati Agung, Kabupaten Lampung Selatan dan Laboratorium Gulma Fakultas Pertanian Universitas Lampung dari bulan November 2016 hingga bulan Maret 2017. Bahan yang digunakan adalah tanaman karet TBM klon IRR 104 berumur 5 tahun, air, kantong plastik, kantong kertas, dan herbisida berbahan aktif isopropilamina glifosat (BITOP 531 SL). Alat yang digunakan antara lain peralatan aplikasi herbisida, oven, arit, cangkul, dan kuadran besi berukuran $0,5 \mathrm{~m}$ x 0,5m. Penelitian ini menggunakan rancangan acak kelompok (RAK) dengan 6 perlakuan dan 4 ulangan (Tabel 1). Pengelompokkan ditetapkan berdasarkan keseragaman gulma yang ada di petak lahan tanaman karet.

Untuk menguji homogenitas ragam data digunakan uji Bartlett dan additivitas data diuji dengan menggunakan uji Tukey. Lalu data dianalisis dengan sidik ragam dan untuk menguji perbedaan nilai tengah perlakuan diuji dengan uji Beda Nyata Terkecil (BNT) pada taraf 5\%. Satuan petak terdiri atas gulma 
dibawah 3 tanaman karet atau dengan luas $3 \mathrm{~m} \times 15 \mathrm{~m}$ (luas $45 \mathrm{~m}^{2}$ ). Petak lahan yang digunakan kondisi penutupan gulmanya $>75 \%$. Aplikasi dilakukan satu kali ketika kondisi lingkungan mendukung (pagi hari, cuaca cerah, dan kecepatan angin rendah). Volume semprot yang diperoleh yaitu 500 1/ha. Penyiangan mekanis dilakukan menggunakan cangkul dengan cara gulma dicangkul hingga kedalaman tanah $\pm 5 \mathrm{~cm}$ saat 0 minggu setelah aplikasi (MSA).

Tabel 1. Susunan perlakuan efikasi herbisida isopropilamina glifosat

\begin{tabular}{clrr}
\hline No. & \multicolumn{1}{c}{ Perlakuan } & $\begin{array}{r}\text { Dosis Bahan Aktif } \\
(\mathrm{g} / \mathrm{ha})\end{array}$ & $\begin{array}{r}\text { Dosis Formulasi } \\
(\mathrm{l} / \mathrm{ha})\end{array}$ \\
\hline 1 & Isopropilamina glifosat & 796,5 & $1,5(3 / 4 \mathrm{~A})$ \\
2 & Isopropilamina glifosat & 1062 & $2,0(\mathrm{~A})$ \\
3 & Isopropilamina glifosat & 1327,5 & $2,5\left(1 \frac{114 \mathrm{~A})}{3,0(11 / 2 \mathrm{~A})}\right.$ \\
4 & Isopropilamina glifosat & 1593 & - \\
5 & Penyiangan mekanis & - & - \\
6 & Kontrol & - & - \\
\hline
\end{tabular}

Keterangan :

$\mathrm{A}=$ Dosis rekomendasi

Pengamatan bobot kering gulma dilakukan pada 4, 8, dan 12 MSA dengan mengambil sampel gulma dari petak penelitian menggunakan 2 kuadran berukuran $0,5 \mathrm{~m}$ x 0,5m secara silang, diharapkan gulma yang diambil dapat mewakili kondisi gulma yang sebenarnya. Kemudian gulma dipilah sesuai spesiesnya dan dioven dengan suhu $80^{\circ} \mathrm{C}$ selama 48 jam hingga bobot kering konstan lalu ditimbang. Nilai SDR gulma (summed dominance ratio) digunakan untuk menentukan urutan gulma dominan dan dapat dicari setelah didapat nilai bobot kering gulma. Perubahan komposisi gulma antar perlakuan pada petak percobaan dapat diketahui dengan rumus koefisien komunitas dengan acuan dari (Tjitrosoedirjo et al., 1984). Kemudian pengamatan fitotoksisitas tanaman karet dengan jumlah sampel yang diamati sebanyak 3 tanaman dalam satuan petak perlakuan. Tingkat keracunan diamati pada 2, 4, dan 6 MSA serta dinilai secara visual terhadap populasi tanaman karet sesuai dengan acuan Direktorat Pupuk dan Pestisida dalam metode standar pengujian efikasi herbisida.

\section{HASIL DAN PEMBAHASAN}

Bobot Kering Gulma Total. Tabel 2 menunjukkan bahwa herbisida isopropilamina glifosat dosis 796,5 - $1.593 \mathrm{~g} /$ ha efektif mengendalikan gulma total pada 4, 8, dan 12 (MSA). Herbisida isopropilamina glifosat antardosis yang diuji tidak menunjukkan perbedaan daya kendali terhadap pertumbuhan gulma total. Hal ini sejalan dengan hasil penelitian (Sinaga, 2004), aplikasi herbisida glifosat pada dosis $760-1.920$ $\mathrm{g} / \mathrm{ha}$ mampu mengendalikan pertumbuhan gulma total hingga 12 MSA.

Pengendalian mekanis menunjukkan daya kendali yang sama dengan herbisida isopropilamina glifosat disemua dosis yang diuji terhadap pertumbuhan gulma total pada 12 MSA. Sementara itu, pada 4 MSA penyiangan mekanis memiliki daya kendali lebih tinggi dari herbisida isopropilamina glifosat dosis 796,5 $1.062 \mathrm{~g} / \mathrm{ha}$. Pada $8 \mathrm{MSA}$ penyiangan mekanis memiliki daya kendali yang sama dengan herbisida isopropilamina glifosat dosis 796,5 g/ha.

Bobot Kering Gulma Golongan Rumput. Tabel 3 menunjukkan bahwa herbisida isopropilamina glifosat dosis 796,5 - $1593 \mathrm{~g} /$ ha efektif mengendalikan gulma golongan rumput mulai dari 4 - 12 MSA. Herbisida isopropilamina glifosat disemua taraf dosis yang diuji mampu menekan gulma golongan rumput dengan daya kendali yang sama dan juga sama dengan penyiangan mekanis. Menurut Sriyani, (2015), glifosat efektif mengendalikan gulma golongan rumput apabila diaplikasikan pascatumbuh. 
Tabel 2. Bobot kering gulma total akibat perlakuan herbisida isopropilamina glifosat

\begin{tabular}{llcc}
\hline Perlakuan & \multirow{2}{*}{$4 \mathrm{MSA}$} & $8 \mathrm{MSA}$ & \multicolumn{1}{c}{12} \\
\hline & $\ldots \ldots \ldots \ldots \ldots\left(\mathrm{g} / 0,5 \mathrm{~m}^{2}\right) \ldots \ldots \ldots \ldots \ldots$ \\
Isopropilamina glifosat $796,5 \mathrm{~g} / \mathrm{ha}$ & $19,51 \mathrm{bc}$ & $10,60 \mathrm{bc}$ & $9,31 \mathrm{~b}$ \\
Isopropilamina glifosat $1062 \mathrm{~g} / \mathrm{ha}$ & $21,59 \mathrm{~b}$ & $2,54 \mathrm{c}$ & $7,07 \mathrm{~b}$ \\
Isopropilamina glifosat $1327,5 \mathrm{~g} / \mathrm{ha}$ & $12,50 \mathrm{bcd}$ & $1,69 \mathrm{c}$ & $7,52 \mathrm{~b}$ \\
Isopropilamina glifosat $1593 \mathrm{~g} / \mathrm{ha}$ & $7,53 \mathrm{~cd}$ & $1,35 \mathrm{c}$ & $4,38 \mathrm{~b}$ \\
Penyiangan Mekanis & $3,51 \mathrm{~d}$ & $17,55 \mathrm{~b}$ & $12,72 \mathrm{~b}$ \\
Kontrol & $47,54 \mathrm{a}$ & $48,66 \mathrm{a}$ & $39,98 \mathrm{a}$ \\
\hline BNT 5\% & 6,52 & 12,02 & 11,96 \\
\hline
\end{tabular}

Keterangan : Nilai tengah pada setiap kolom yang diikuti huruf yang sama tidak berbeda nyata menurut uji BNT pada taraf $5 \%$.

Bobot Kering Gulma Golongan Daun Lebar. Tabel 4 menunjukkan bahwa herbisida isopropilamina glifosat dosis 796,5 - 1.327,5 g/ha tidak mampu mengendalikan gulma daun lebar. Pada dosis $1593 \mathrm{~g} / \mathrm{ha}$ efektif mengendalikan gulma daun lebar dan daya kendali antardosis herbisida sama. Pada 8 MSA, dosis 796,5; 1.062; dan 1.327,5 g/ha menunjukkan daya kendali yang sama dalam mengendalikan gulma daun lebar, namun dosis $1.593 \mathrm{~g} / \mathrm{ha}$ memperlihatkan daya kendali yang lebih tinggi dari 796,5 g/ha. Pada $12 \mathrm{MSA}$, herbisida isopropilamina glifosat disemua taraf dosis yang diuji tidak efektif mengendalikan gulma daun lebar. Hal ini disebabkan karena terjadi pertumbuhan gulma baru (new-growth) pada petak herbisida isopropilamina glifosat. Hasil pengamatan ini sejalan dengan hasil penelitian (Oktavia, 2014), herbisida glifosat pada dosis $720,1.200$, dan $1.440 \mathrm{~g} /$ ha tidak mampu menekan pertumbuhan gulma daun lebar pada 12 MSA.

Tabel 3. Bobot kering gulma golongan rumput akibat perlakuan herbisida isopropilamina glifosat

\begin{tabular}{llcc}
\hline Perlakuan & $4 \mathrm{MSA}$ & $8 \mathrm{MSA}$ & $12 \mathrm{MSA}$ \\
\hline & $\ldots \ldots \ldots \ldots \ldots\left(\mathrm{g} / 0,5 \mathrm{~m}^{2}\right) \ldots \ldots \ldots \ldots \ldots$ \\
Isopropilamina glifosat $796,5 \mathrm{~g} / \mathrm{ha}$ & $6,93 \mathrm{~b}$ & $3,80 \mathrm{~b}$ & $3,84 \mathrm{~b}$ \\
Isopropilamina glifosat $1062 \mathrm{~g} / \mathrm{ha}$ & $8,47 \mathrm{~b}$ & $0,75 \mathrm{~b}$ & $2,73 \mathrm{~b}$ \\
Isopropilamina glifosat $1327,5 \mathrm{~g} / \mathrm{ha}$ & $9,57 \mathrm{~b}$ & $0,21 \mathrm{~b}$ & $4,69 \mathrm{~b}$ \\
Isopropilamina glifosat $1593 \mathrm{~g} / \mathrm{ha}$ & $5,37 \mathrm{~b}$ & $0,70 \mathrm{~b}$ & $2,49 \mathrm{~b}$ \\
Penyiangan mekanis & $1,59 \mathrm{~b}$ & $3,68 \mathrm{~b}$ & $8,46 \mathrm{~b}$ \\
Kontrol & $29,19 \mathrm{a}$ & $31,05 \mathrm{a}$ & $34,19 \mathrm{a}$ \\
\hline BNT 5\% & 10,36 & 7,91 & 13,00 \\
\hline
\end{tabular}

Keterangan : Nilai tengah pada setiap kolom yang diikuti huruf yang sama tidak berbeda nyata menurut uji BNT pada taraf $5 \%$.

Bobot Kering Gulma Golongan Teki. Tabel 5 menunjukkan bahwa pada 4 MSA, herbisida isopropilamina glifosat dosis 796,5 - $1.593 \mathrm{~g} / \mathrm{ha}$ mampu mengendalikan gulma teki pada dengan daya kendali yang sama. Sementara pada 8 dan 12 MSA, herbisida isopropilamina glifosat disemua taraf dosis yang diuji tidak mampu mengendalikan gulma teki. Penyiangan mekanis pada 4 MSA menunjukkan daya kendali yang sama dengan herbisida isopropilamina glifosat, sedangkan pada 8 dan 12 MSA penyiangan mekanis tidak dapat mengendalikan gulma teki. 
Pamungkas dkk: Efikasi Herbisida Isopropilamina dalam Mengendalikan Gulma ...

Tabel 4. Bobot kering gulma golongan daun lebar akibat perlakuan herbisida isopropilamina glifosat

\begin{tabular}{lllcc}
\hline \multirow{2}{*}{ Perlakuan } & \multirow{2}{*}{4 MSA } & \multirow{2}{*}{$8 \mathrm{MSA}$} & \multicolumn{2}{c}{$12 \mathrm{MSA}$} \\
\cline { 5 - 5 } & & $\ldots \ldots \ldots \ldots \ldots \ldots \ldots\left(\mathrm{g} / 0,5 \mathrm{~m}^{2}\right) \ldots \ldots \ldots \ldots \ldots \ldots \ldots \ldots$ \\
Isopropilamina glifosat $796,5 \mathrm{~g} / \mathrm{ha}$ & $11,48 \mathrm{ab}$ & $4,52 \mathrm{bc}$ & 3,32 & $1,14 \mathrm{a}$ \\
Isopropilamina glifosat $1062 \mathrm{~g} / \mathrm{ha}$ & $11,92 \mathrm{ab}$ & $1,14 \mathrm{bcd}$ & 2,96 & $1,13 \mathrm{a}$ \\
Isopropilamina glifosat $1327,5 \mathrm{~g} / \mathrm{ha}$ & $1,60 \mathrm{ab}$ & $0,72 \mathrm{~cd}$ & 1,43 & $1,07 \mathrm{a}$ \\
Isopropilamina glifosat $1593 \mathrm{~g} / \mathrm{ha}$ & $1,20 \mathrm{~b}$ & $0,23 \mathrm{~d}$ & 1,70 & $1,09 \mathrm{a}$ \\
Penyiangan mekanis & $0,69 \mathrm{~b}$ & $5,12 \mathrm{~b}$ & 2,63 & $1,15 \mathrm{a}$ \\
Kontrol & $13,27 \mathrm{a}$ & $12,91 \mathrm{a}$ & 3,27 & $1,23 \mathrm{a}$ \\
\hline BNT 5\% & 21,43 & 4,01 & 0,16 \\
\hline Keterangan $\quad$ Nilai tengah pada setiap kolom yang diikuti huruf yang sama tidak berbeda nyata menurut uji BNT
\end{tabular}

Hal ini disebabkan karena herbisida isopropilamina glifosat hanya mampu meracuni secara sistemik tunas - tunas muda gulma teki tanpa mampu meracuni sistem perakaran atau umbinya. Menurut $\mathrm{K}$ dan Budianto, 2011), sistem akar rimpang dan umbi yang kompleks pada gulma teki menyebabkan teki lebih tahan terhadap herbisida. Hal ini diperkuat oleh hasil penelitian Ngawit \& Budianto, (2011) bahwa aplikasi glifosat dosis $1000 \mathrm{~g} / \mathrm{ha}$ nyata menekan pertumbuhan gulma teki pada 4 MSA, namun kemampuan tumbuh dan berkembangnya masih tetap tinggi.

Tabel 5. Bobot kering gulma golongan teki akibat perlakuan herbisida isopropilamina glifosat

\begin{tabular}{llrr}
\hline Perlakuan & \multicolumn{2}{c}{12} \\
\hline & $4 \mathrm{MSA}$ & $8 \mathrm{MSA}$ & $\mathrm{MSA}$ \\
\hline Isopropilamina glifosat $796,5 \mathrm{~g} / \mathrm{ha}$ & $\ldots \ldots \ldots \ldots \ldots\left(\mathrm{g} / 0,5 \mathrm{~m}^{2}\right) \ldots \ldots \ldots \ldots \ldots$ \\
Isopropilamina glifosat $1062 \mathrm{~g} / \mathrm{ha}$ & $1,10 \mathrm{~b}$ & $2,27 \mathrm{a}$ & $2,15 \mathrm{a}$ \\
Isopropilamina glifosat $1327,5 \mathrm{~g} / \mathrm{ha}$ & $1,19 \mathrm{~b}$ & $0,66 \mathrm{a}$ & $1,39 \mathrm{a}$ \\
Isopropilamina glifosat $1593 \mathrm{~g} / \mathrm{ha}$ & $0,93 \mathrm{~b}$ & $0,77 \mathrm{a}$ & $1,40 \mathrm{a}$ \\
Penyiangan Mekanis & $1,24 \mathrm{~b}$ & $8,42 \mathrm{a}$ & $0,19 \mathrm{a}$ \\
Kontrol & $5,08 \mathrm{a}$ & $4,70 \mathrm{a}$ & $1,63 \mathrm{a}$ \\
\hline BNT 5\% & 3,43 & 8,44 & $0,24 \mathrm{a}$ \\
\hline
\end{tabular}

Keterangan : Nilai tengah pada setiap kolom yang diikuti huruf yang sama tidak berbeda nyata menurut uji BNT pada taraf $5 \%$.

Bobot Kering Gulma Ottochloa nodosa. Tabel 6 menunjukkan bahwa pada 4 MSA herbisida isopropilamina glifosatdosis 796,5 dan 1.062 tidak mampu menekan pertumbuhan gulma $O$. nodosa, berbeda dengan dosis $1.327,5$ dan $1.593 \mathrm{~g} /$ ha efektif mengendalikan gulma tersebut dan daya kendali antardosis sama. Sedangkan pada 8 dan 12 MSA, herbisida isopropilamina glifosat dosis 769,5 - 1.593 g/ha mampu mengendalikan gulma $O$. nodosa dengan daya kendali yang sama.

Secara umum hanya herbisida isopropilamina glifosat dosis 1.327,5 - 1.593 yang efektif mengendalikan gulma $O$. nodosa hingga 12 MSA. Sementara itu, penyiangan mekanis menunjukkan daya kendali yang sama dengan herbisida isopropilamina glifosat dosis 796,5 - 1.593 pada 4, 8, dan 12 MSA. Hasil pengamatan ini sejalan dengan hasil penelitian (Sigalingging, 2013), bahwa aplikasi herbisida isopropilamina glifosat efektif mengendalikan gulma $O$. nodosa dari dosis terendah yang digunakannya yaitu $1.080 \mathrm{~g} / \mathrm{ha}-2.160 \mathrm{~g} / \mathrm{ha}$ yang memiliki daya kendali yang sama. 
Tabel 6. Bobot kering gulma Ottochloa nodosa akibat perlakuan herbisida isopropilamina glifosat

\begin{tabular}{llcc}
\hline Perlakuan & $4 \mathrm{MSA}$ & $8 \mathrm{MSA}$ & $12 \mathrm{MSA}$ \\
\hline & $\ldots \ldots \ldots \ldots \ldots\left(\mathrm{g} / 0,5 \mathrm{~m}^{2}\right) \ldots \ldots \ldots \ldots \ldots$ \\
Isopropilamina glifosat $796,5 \mathrm{~g} / \mathrm{ha}$ & $2,91 \mathrm{ab}$ & $1,38 \mathrm{~b}$ & $2,31 \mathrm{~b}$ \\
Isopropilamina glifosat $1062 \mathrm{~g} / \mathrm{ha}$ & $3,64 \mathrm{ab}$ & $0,44 \mathrm{~b}$ & $0,24 \mathrm{~b}$ \\
Isopropilamina glifosat $1327,5 \mathrm{~g} / \mathrm{ha}$ & $2,01 \mathrm{~b}$ & $0,13 \mathrm{~b}$ & $1.53 \mathrm{~b}$ \\
Isopropilamina glifosat $1593 \mathrm{~g} / \mathrm{ha}$ & $0,78 \mathrm{~b}$ & $0,63 \mathrm{~b}$ & $2.06 \mathrm{~b}$ \\
Penyiangan mekanis & $0,33 \mathrm{~b}$ & $0,40 \mathrm{~b}$ & $4,19 \mathrm{~b}$ \\
Kontrol & $8,32 \mathrm{a}$ & $8,98 \mathrm{a}$ & $10,18 \mathrm{a}$ \\
\hline BNT 5\% & 5,89 & 6,65 & 4,77 \\
\hline
\end{tabular}

Keterangan : Nilai tengah pada setiap kolom yang diikuti huruf yang sama tidak berbeda nyata menurut uji BNT pada taraf $5 \%$.

Bobot Kering Gulma Asystasia gangetica. Tabel 7 menunjukkan bahwa herbisida isopropilamina glifosat efektif mengendalikan gulma Asystasia gangetica pada 4 MSA, sedangkan antardosis herbisida isopropilamina glifosat yang diuji dan penyiangan mekanis tidak menunjukkan perbedaan daya kendali. Pada 8 MSA herbisida isopropilamina glifosat dosis 796,5 - 1.327,5 g/ha tidak mampu menekan pertumbuhan gulma A. gangetica, namun dosis $1.593 \mathrm{~g} / \mathrm{ha}$ efektif mengendalikan gulma A. gangetica. Pada 12 MSA herbisida isopropilamina glifosat disemua taraf dosis yang diuji dan penyiangan mekanis tidak efektif mengendalikan gulma A. gangetica. Hasil penelitian ini sesuai dengan pendapat (Sigalingging, 2013), herbisida glifosat efektif mengendalikan berbagai jenis gulma berdaun lebar.

Pada 8 MSA herbisida isopropilamina glifosat dosis 796,5 - 1.327,5 g/ha dan pada 12 MSA disemua taraf dosis yang diuji tidak mampu menekan pertumbuhan gulma A. gangetica, hal ini disebabkan karena gulma telah mengalami pemulihan. Hasil penelitian Oktavia, (2014) memperlihatkan hal yang sama bahwa herbisida glifosat 720, 1.200, dan $1.440 \mathrm{~g} /$ ha tidak efektif mengendalikan gulma daun lebar pada $12 \mathrm{MSA}$.

Tabel 7. Bobot kering gulma Asystasia gangetica akibat perlakuan herbisida isopropilamina glifosat

\begin{tabular}{llcc}
\hline Perlakuan & \multirow{2}{*}{$4 \mathrm{MSA}$} & $8 \mathrm{MSA}$ & \multicolumn{1}{c}{12} \\
\hline & $\ldots \ldots \ldots \ldots \ldots\left(\mathrm{g} / 0,5 \mathrm{~m}^{2}\right) \ldots \ldots \ldots \ldots \ldots$ \\
Isopropilamina glifosat $796,5 \mathrm{~g} / \mathrm{ha}$ & $1,68 \mathrm{~b}$ & $0,83 \mathrm{ab}$ & $1,08 \mathrm{a}$ \\
Isopropilamina glifosat $1062 \mathrm{~g} / \mathrm{ha}$ & $0,95 \mathrm{~b}$ & $0,72 \mathrm{ab}$ & $0,92 \mathrm{a}$ \\
Isopropilamina glifosat $1327,5 \mathrm{~g} / \mathrm{ha}$ & $0,15 \mathrm{~b}$ & $0,51 \mathrm{ab}$ & $0,55 \mathrm{a}$ \\
Isopropilamina glifosat $1593 \mathrm{~g} / \mathrm{ha}$ & $0,32 \mathrm{~b}$ & $0,10 \mathrm{~b}$ & $0,95 \mathrm{a}$ \\
Penyiangan mekanis & $0,63 \mathrm{~b}$ & $1,95 \mathrm{ab}$ & $1,54 \mathrm{a}$ \\
Kontrol & $6,61 \mathrm{a}$ & $2,77 \mathrm{a}$ & $2,07 \mathrm{a}$ \\
\hline BNT 5\% & 3,11 & 2,33 & 1,60 \\
\hline
\end{tabular}

Keterangan $\quad$ : Nilai tengah pada setiap kolom yang diikuti huruf yang sama tidak berbeda nyata menurut uji BNT pada taraf $5 \%$.

Bobot Kering Gulma Commelina diffusa. Tabel 8 menunjukkan bahwa herbisida isopropilamina glifosat dosis 796,5 - $1.062 \mathrm{~g} / \mathrm{ha}$ tidak mampu menekan pertumbuhan gulma Commelina diffusa, namun dosis $1.327,5$ - $1.593 \mathrm{~g} /$ ha efektif mengendalikan gulma $C$. diffusa. Sedangkan pada 8 dan 12 MSA, herbisida isopropilamina glifosat disemua taraf dosis yang diuji tidak mampu menekan pertumbuhan gulma C. diffusa, sama halnya dengan pengendalian mekanis.

Aplikasi glifosat dapat menekan gulma $C$. diffusa, pada 4 MSA terjadi keracunan pada gulma tersebut namun pada 8 MSA gulma yang teracuni tumbuh kembali (re-growth) dimana tumbuh ruas - ruas bari dari batangnya (Sinaga, 2004). Hal yang sama merupakan penyebab gulma $C$. diffusa pada 8 MSA pulih dan 
tumbuh kembali menjadi normal. Selain itu $C$. diffusa memiliki buku dan mengandung air pada batangnya, adanya lapisan lilin yang menyelimuti batang dan daun yang merupakan penyebab glifosat sulit masuk kedalam jaringan gulma kecuali pada dosis tinggi.

Tabel 8. Bobot kering gulma Commelina diffusa akibat perlakuan herbisida isopropilamina glifosa

\begin{tabular}{llcc}
\hline Perlakuan & $4 \mathrm{MSA}$ & $8 \mathrm{MSA}$ & $12 \mathrm{MSA}$ \\
\hline & $\ldots \ldots \ldots \ldots \ldots\left(\mathrm{g} / 0,5 \mathrm{~m}^{2}\right) \ldots \ldots \ldots \ldots \ldots$ \\
Isopropilamina glifosat $796,5 \mathrm{~g} / \mathrm{ha}$ & $0,87 \mathrm{abc}$ & $0,49 \mathrm{a}$ & $0,41 \mathrm{ab}$ \\
Isopropilamina glifosat $1062 \mathrm{~g} / \mathrm{ha}$ & $1,31 \mathrm{ab}$ & $0,05 \mathrm{a}$ & $1,93 \mathrm{a}$ \\
Isopropilamina glifosat $1327,5 \mathrm{~g} / \mathrm{ha}$ & $0,01 \mathrm{c}$ & $0,12 \mathrm{a}$ & $0,15 \mathrm{~b}$ \\
Isopropilamina glifosat $1593 \mathrm{~g} / \mathrm{ha}$ & $0,15 \mathrm{bc}$ & $0,09 \mathrm{a}$ & $0,31 \mathrm{~b}$ \\
Penyiangan mekanis & $0,05 \mathrm{bc}$ & $0,73 \mathrm{a}$ & $0,92 \mathrm{ab}$ \\
Kontrol & $1,55 \mathrm{a}$ & $0,73 \mathrm{a}$ & $0,01 \mathrm{~b}$ \\
\hline BNT 5\% & 1,29 & 1,10 & 1,61 \\
\hline
\end{tabular}

Keterangan $\quad$ : Nilai tengah pada setiap kolom yang diikuti huruf yang sama tidak berbeda nyata menurut uji BNT pada taraf $5 \%$.

Bobot Kering Gulma Cyperus brevifolius. Tabel 9 menunjukkan bahwa pada 4 MSA herbisida isopropilamina glifosat disemua taraf dosis yang diuji efektif mengendalikan gulma Cyperus brevifolius dan menunjukkan daya kendali yang sama dengan penyiangan mekanis. Sedangkan pada 8 dan 12 MSA, herbisida isopropilamina glifosat disemua taraf dosis yang diuji dan penyiangan mekanis tidak mampu menekan pertumbuhan gulma C. brevifolius dan tidak menunjukkan perbedaan daya kendali.

Tabel 9. Bobot kering gulma Cyperus brevifolius akibat perlakuan herbisida isopropilamina glifosat

\begin{tabular}{llcc}
\hline Perlakuan & \multirow{2}{*}{$4 \mathrm{MSA}$} & $8 \mathrm{MSA}$ & \multicolumn{1}{c}{12} \\
\hline & & $\mathrm{MSA} \ldots \ldots \ldots \ldots\left(\mathrm{g} / 0,5 \mathrm{~m}^{2}\right) \ldots \ldots \ldots \ldots \ldots$ & \\
Isopropilamina glifosat $796,5 \mathrm{~g} / \mathrm{ha}$ & $1,10 \mathrm{~b}$ & $2,03 \mathrm{ab}$ & $2,15 \mathrm{a}$ \\
Isopropilamina glifosat $1062 \mathrm{~g} / \mathrm{ha}$ & $1,19 \mathrm{~b}$ & $0,64 \mathrm{~b}$ & $1,39 \mathrm{a}$ \\
Isopropilamina glifosat $1327,5 \mathrm{~g} / \mathrm{ha}$ & $1,33 \mathrm{~b}$ & $0,74 \mathrm{~b}$ & $0,85 \mathrm{a}$ \\
Isopropilamina glifosat $1593 \mathrm{~g} / \mathrm{ha}$ & $0,96 \mathrm{~b}$ & $0,42 \mathrm{~b}$ & $0,17 \mathrm{a}$ \\
Penyiangan Mekanis & $1,24 \mathrm{~b}$ & $5,49 \mathrm{a}$ & $0,93 \mathrm{a}$ \\
Kontrol & $5,08 \mathrm{a}$ & $4,70 \mathrm{ab}$ & $0,24 \mathrm{a}$ \\
\hline BNT 5\% & 3,43 & 4,54 & 2,08 \\
\hline
\end{tabular}

Keterangan : Nilai tengah pada setiap kolom yang diikuti huruf yang sama tidak berbeda nyata menurut uji BNT pada taraf $5 \%$.

Menurut Novalinda, (2014), C. brefivolius termasuk golongan gulma teki yang tumbuh dilahan yang ternaungi dan terbuka pada tanah yang belum maupun sudah diolah. Lebih lanjut Lailiyah, (2014) menyatakan bahwa gulma teki memiliki akar bercabang yang luas dan terdapat umbi yang jumlahnya banyak dan berkembang dengan baik. Hal inilah yang menyebabkan bahwa herbisida isopropilamina glifosat tidak meracuni perakaran gulma secara menyeluruh, sehingga menyebabkan ketidakmampuannya dalam menekan pertumbuhan gulma C. brefivolius pada 8 - 12 MSA.

Perbedaan Komposisi Gulma (Koefisien Komunitas). Tabel 10, pada 4 MSA ditemukan perbedaan komposisi gulma dengan nilai (C) antara $41-72 \%$, namun hanya herbisida isopropilamina glifosat dosis $796,5 \mathrm{~g} /$ ha yang memiliki komposisi gulma yang sama dengan dosis $1.062 \mathrm{~g} /$ ha sebesar $89 \%$. Pada 8 MSA diketahui perbedaan komposisi gulma dengan nilai koefisien komunitas (C) antara $44-71 \%$, namun hanya herbisida isopropilamina glifosat dosis $796,5 \mathrm{~g} /$ ha yang memiliki komposisi gulma yang sama sebesar $76 \%$ dengan perlakuan kontrol. Pada 12 MSA diketahui perbedaan komposisi gulma dengan nilai koefisien 
komunitas (C) antara 58 - 74\%. Pada 12 MSA terjadi perubahan komposisi gulma pada semua petak perlakuan herbisida isopropilamina glifosat disemua taraf dosis yang diuji.

Fitotoksisitas Tanaman Karet. Pengamatan fitotoksisitas telah dilakukan secara visual pada 2, 4 dan 6 MSA. Hasil pengamatan menunjukkan bahwa tidak adanya gejala keracunan akibat aplikasi herbisida isopropilamina glifosat dosis 796,5 - $1.593 \mathrm{~g} / \mathrm{ha}$ dalam mengendalikan gulma pada baris tanaman karet. Hasil pengamatan ini sama dengan hasil penelitian Girsang, (2005), bahwa herbisida glifosat dosis >360 g/ha tidak meracuni tanaman karet hingga 12 MSA. Tidak terjadinya keracunan ditunjukkan dengan tidak adanya perbedaan pada tanaman karet yang dibandingkan dengan tanaman karet pada perlakuan penyiangan mekanis. Pada tanaman karet tidak terdapat perubahan bentuk dan atau warna daun, serta pertumbuhan tanaman karet tetap normal. Daun tanaman karet terlihat berwarna hijau dan bentuknya normal, tidak terjadi penggulungan dan atau pengkritingan pada daun sehingga dapat dikatakan bahwa tidak terdapat gejala keracunan pada tanaman karet akibat aplikasi herbisida isopropilamina glifosat.

Tabel 10. Koefisien komunitas 4, 8, dan 12 MSA (\%)

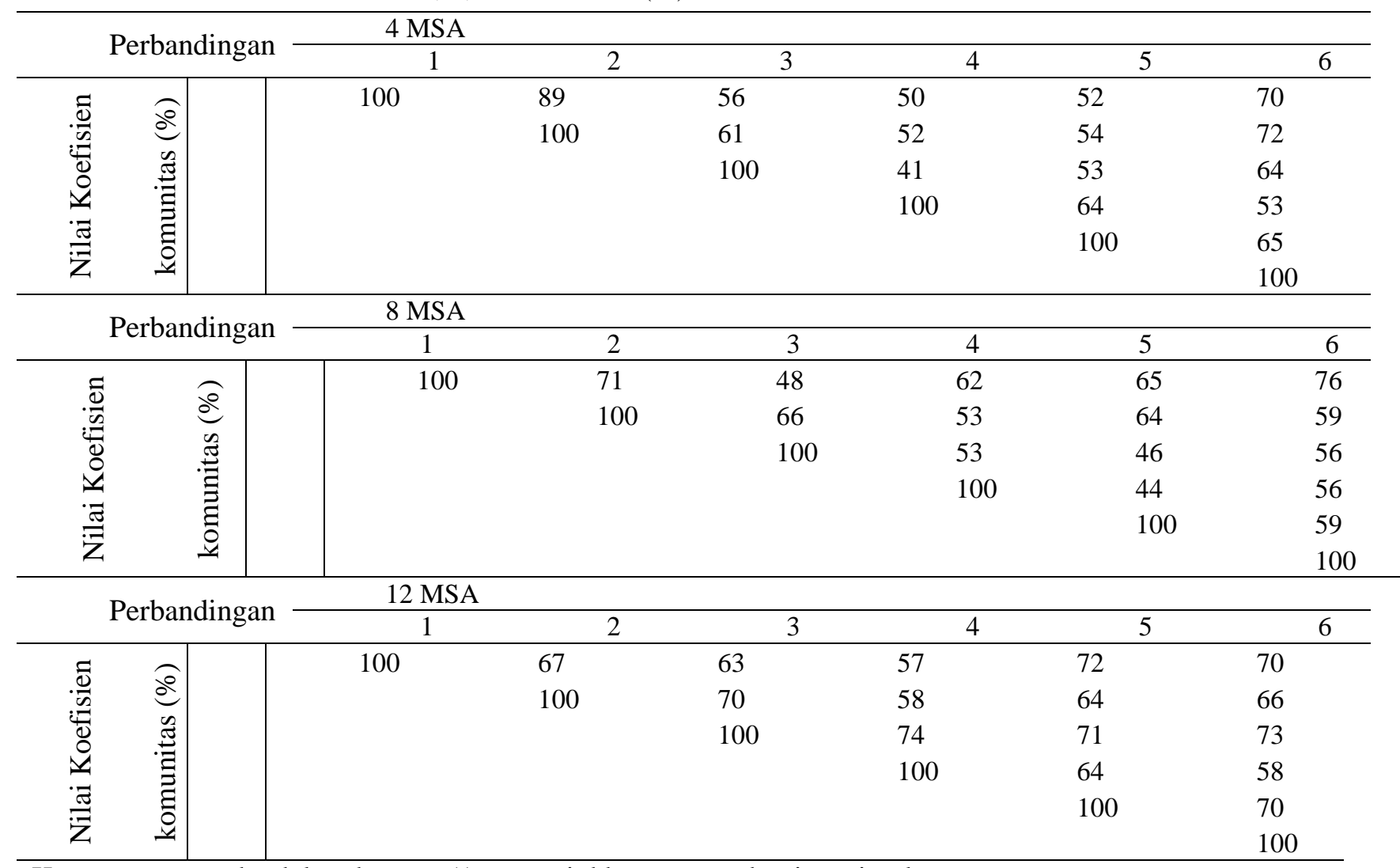

Keterangan : angka dalam kurung ( ) menunjukkan urutan dominansi gulma

$1=$ Isopropilamina glifosat $796,5 \mathrm{~g} / \mathrm{ha} \quad 4=$ Isopropilamina glifosat $1593 \mathrm{~g} / \mathrm{ha}$

$2=$ Isopropilamina glifosat $1062 \mathrm{~g} / \mathrm{ha} \quad 5=$ Penyiangan mekanis

$3=$ Isopropilamina glifosat $1327,5 \mathrm{~g} / \mathrm{ha} \quad 6=$ Kontrol

\section{KESIMPULAN}

Berdasarkan uraian diatas dapat disimpulkan bahwa (1) Herbisida isopropilamina glifosat dosis 796,5 - $1593 \mathrm{~g} / \mathrm{ha}$ efektif mengendalikan gulma total, gulma rumput hingga 12 MSA dan gulma teki hingga 4 MSA, serta dosis $1593 \mathrm{~g} /$ ha efektif mengendalikan gulma daun lebar hingga 8 MSA.; (2) Herbisida isopropilamina glifosat dosis 1327,5 - 1593 g/ha efektif mengendalikan gulma Ottochloa nodosa hingga 12 MSA dan Commelina diffusa hingga 4 MSA; (3) Herbisida isopropilamina glifosat dosis 796,5 - $1593 \mathrm{~g} / \mathrm{ha}$ efektif mengendalikan gulma Cyperus brevifolius hingga 4 MSA, serta dosis 1593 g/ha efekti mengendalikan 
gulma Asystasia gangetica hingga 8 MSA; (4) Herbisida isopropilamina glifosat dosis 796,5 - $1593 \mathrm{~g} / \mathrm{ha}$ menyebabkan terjadinya perubahan komposisi gulma pada 4, 8, dan 12 MSA dan (5) Herbisida isopropilamina glifosat dosis dosis 796,5 - $1593 \mathrm{~g} /$ ha tidak meracuni tanaman karet.

\section{DAFTAR PUSTAKA}

Badan Pusat Statistik 2016. Produksi Karet di Indonesia .

Direktorat Jendral Perkebunan 2016. Statistik Perkebunan Indonesia Komoditas Karet.

Evrizal, R. 2015. Karet:Manajemen dan Pengelolaan Kebun. Yogyakarta: CV Graha Ilmu.

Ferry, Y. \& Samsudin, S. 2014. Keragaan Tanaman Karet Rakyat dan Penerapan Teknologi Budidayanya di Kabupaten Karimun. SIRINOV, 2(2): 101-112.

Girsang, W. 2005. Pengaruh Tingkat Dosis Herbisida Isopropilamina Glifosat dan Selang Waktu Terjadinya Pencucian Setelah Aplikasi terhadap Efektifitas Pengendalian Gulma pada Perkebunan Karet (Hevea brassiliensis) TBM. Jurnal Penelitian Bidang Ilmu Pertanian., 3(2): 31-36.

Lailiyah, W. 2014. Pengaruh Periode Penyiangan Gulma terhadap Pertumbuhan dan Hasil Tanaman Kacang Panjang (Vigna sesquipedalis L.). Jurnal Produksi Tanaman, 2(7): 606-612.

Ngawit, I. \& Budianto, V. 2011. Uji Kemampuan Beberapa Jenis Herbisida terhadap Gulma pada Tanaman Kacang Tanah dan Dampaknya terhadap Pertumbuhan dan Aktivitas Bakteri Rhizobium di dalam Tanah. Crop Agro, 4(2): 27-36. Tersedia di http://www.tandfonline.com/doi/abs/10.1080/01402390.2011.569130\%5Cnhttp://proxy.library.upenn.e du:2195/doi/abs/10.1080/01402390.2011.569130.

Novalinda, R. 2014. Analisis Vegetasi pada Perkebunan Karet (Hevea brasiliensis Mull.Arg.) di Kecamatan Batang Kapas, Pesisir Barat. J. Bio UA, 3(2): 129-134. Tersedia di https://www.cambridge.org/core/product/identifier/S0007125000277040/type/journal_article.

Oktavia, E. 2014. Efikasi Herbisida Glifosat terhadap Gulma Umum pada Perkebunan Karet (Hevea brasiliensis [Muell.] Arg) Menghasilkan. Universitas Lampung.

Purwanta, J.H., Kiswanto, K. \& Slameto, S. 2008. Teknologi Budidaya Karet. Bogor.

Sigalingging, D.R. 2013. Efikasi Herbisida Glifosat untuk Mengendalikan Gulma pada Pertanaman Kopi.

Sinaga, D.F. 2004. Efektivitas Herbisida Glifosat untuk Mengendalikan Gulma pada Tanaman Karet (Hevea brasiliensis) Belum Menghasilkan.

Sriyani, N. 2015. Bahan Kuliah Ilmu dan Teknik Pengendalian Gulma. Diktat. Bandar Lampung: Universitas Lampung.

Suparwan, I. \& Haryadi, H. 2014. Efektivitas Herbisida IPA Glifosat 486 SL Untuk Pengendalian Gulma pada Budidaya Tanaman Karet (Hevea brasiliensis Muell. Arg) Belum Menghasilkan. Bul. Agrohorti., 2(1): 95-103. Tersedia di https://www.cambridge.org/core/product/identifier/S0007125000277040/type/journal_article.

Tjitrosoedirjo, S., Utomo, I.H. \& Wiroatmodjo, (Eds) 1984. Pengelolaan Gulma di Perkebunan. Kerjasama Biotrop Bogor. Jakarta: PT Gramedia Pustaka Utama. 